\title{
Association of Circulating Magnesium Levels in Patients With Alzheimer's Disease From 1991 to 2021: A Systematic Review and Meta-Analysis
}

\section{OPEN ACCESS}

Edited by:

Ramesh Kandimalla,

Indian Institute of Chemical

Technology (CSIR), India

Reviewed by:

Peng Wang,

Anhui Medical University, China Vahidreza Ostadmohammadi,

Kashan University of Medical

Sciences, Iran

*Correspondence: Ming-Yan Liu

liumy_cmu@163.com

Specialty section:

This article was submitted to Alzheimer's Disease and Related

Dementias,

a section of the journal

Frontiers in Aging Neuroscience

Received: 22 October 2021 Accepted: 15 December 2021

Published: 10 January 2022

Citation:

Du K, Zheng X, Ma Z-T, Lv J-Y, Jiang W-J and Liu M-Y (2022) Association of Circulating Magnesium Levels in Patients With Alzheimer's Disease From 1991 to 2021: A Systematic Review and Meta-Analysis. Front. Aging Neurosci. 13:799824. doi: 10.3389/fnagi.2021.799824

\author{
Ke Du ${ }^{1}$, Xi Zheng ${ }^{1}$, Zi-Tai Ma ${ }^{1}$, Jun-Ya Lv ${ }^{1}$, Wen-Juan Jiang ${ }^{1,2}$ and Ming-Yan Liu ${ }^{1 *}$ \\ ${ }^{1}$ Department of Pharmacology, School of Pharmacy, China Medical University, Shenyang, China, ${ }^{2}$ Department of Geriatrics, \\ The First Affiliated Hospital of China Medical University, Shenyang, China
}

Alzheimer's disease (AD) remains a medical and social challenge worldwide. Magnesium $(\mathrm{Mg})$ is one of the most frequently evaluated essential minerals with diverse biological functions in human body. However, the association between circulating Mg levels and AD remains controversial. We conducted a meta-analysis of 21 studies published between 1991 and 2021 to determine whether the Mg levels in the blood and cerebrospinal fluid (CSF) are abnormal in AD. Literatures were searched in PubMed, Web of Science, China National Knowledge Infrastructure (CNKI), and Wanfang Data without language limitations. A pooled subject sample including 1,112 AD patients and 1,001 healthy controls (HCs) was available to assess Mg levels in serum and plasma; 284 AD patients and $117 \mathrm{HCs}$ were included for Mg levels in CSF. It was found that serum and plasma levels of Mg were significantly reduced in AD patients compared with HCs (standardized mean difference $[\mathrm{SMD}]=-0.89 ; 95 \%$ confidence interval $[\mathrm{Cl}][-1.36,-0.43] ; P=$ 0.000). There was statistically non-significant for Mg level in CSF between AD and HCs, whereas a decreased tendency were detected (SMD $=-0.16 ; 95 \% \mathrm{Cl}[-0.50,0.18]$; $P=0.364)$. . In addition, when we analyzed the Mg levels of serum, plasma and CSF together, the circulating $\mathrm{Mg}$ levels in $\mathrm{AD}$ patients was significantly lower (SMD $=-0.74$, $95 \% \mathrm{Cl}[-1.13 ;-0.35] ; P=0.000)$. These results indicate that $\mathrm{Mg}$ deficiency may be a risk factor of $A D$ and $M g$ supplementation may be a potentially valuable adjunctive treatment for AD.

Systematic Review Registration: www.crd.york.ac.uk/PROSPERO/, registration number CRD42021254557.

Keywords: magnesium, serum, plasma, CSF, Alzheimer's disease, meta-analysis

\section{INTRODUCTION}

Alzheimer's disease $(\mathrm{AD})$ is the most common cause of dementia, typified by cognitive impairment and brain lesions. The typical pathological changes include plaques formed by beta-amyloid (A $\beta$ ) aggregation and intracellular neurofibrillary tangles, as well as prolonged inflammation (Akiyama et al., 2000; Lesne et al., 2006). Although there are many basic and clinical researches on AD, the etiology of $\mathrm{AD}$ has not been comprehensively elucidated. Currently, $\mathrm{AD}$ treatment largely depends on cholinesterase inhibitors, which is only a symptomatic therapy. It means that these drugs have 
limited efficacy on AD progression (Sharma, 2019). Therefore, it is necessary to evaluate the risk factors for $\mathrm{AD}$ to provide an opportunity for delaying the $\mathrm{AD}$ progression.

Notably, the dyshomeostasis of nutritional minerals has been associated with $\mathrm{AD}$ progression (Gonzalez-Dominguez et al., 2014). Previous studies have proposed the imbalance of several minerals, such as zinc (Ventriglia et al., 2015; Kawahara et al., 2018), iron (Belaidi and Bush, 2016; Lane et al., 2018), copper (Donnelly et al., 2007; Sensi et al., 2018), and manganese (Du et al., 2017; Mezzaroba et al., 2019), as risk factors in $\mathrm{AD}$. Magnesium $(\mathrm{Mg})$ is an essential for the maintenance of human health. Mg plays a critical role in nerve transmission and neuromuscular conduction in nervous system and has a protective effect against excitotoxicity inducing neuronal death (Kirkland et al., 2018). It is associated with multiple neurological disorders in central nervous system, including migraine (Chiu et al., 2016; Dolati et al., 2020), epilepsy (Abdullahi et al., 2019; Yary and Kauhanen, 2019) and Parkinson's disease (Oyanagi and Hashimoto, 2011; Shen et al., 2019). Recently, $\mathrm{Mg}$ investigations are paid more attention in $\mathrm{AD}$ researchers. However, contradictory results exist regarding abnormal $\mathrm{Mg}$ levels in $\mathrm{AD}$ patients. Several reports have described the systemic levels of $\mathrm{Mg}$ were significantly reduced in AD (Lemke, 1995; Kurup and Kurup, 2003; Cilliler et al., 2007; Vural et al., 2010; Barbagallo et al., 2011; Singh et al., 2014; Ahmed et al., 2017; Balmus et al., 2017), but others have reported no differences or even elevated Mg levels in AD patients (Zhu et al., 1997; Cheng et al., 1999; Alimonti et al., 2007; Liu, 2008; Bostrom et al., 2009a,b; Gustaw-Rothenberg et al., 2010; Hozumi et al., 2011; Koc et al., 2015; Wang, 2015; Zheng, 2015; Xu et al., 2018; Jouini et al., 2021). However, these studies only involved single case-control investigations with small sample size. Therefore, they may lack sufficient power, leading to limitation the scope of their findings.

Here, we conducted a systematic review to comprehensively estimate variations in circulating $\mathrm{Mg}$ levels (in the plasma, serum, and cerebrospinal fluid [CSF]) in $\mathrm{AD}$ patients compared with healthy controls (HCs). The aim of the present study was to gain additional insights into maintaining an adequate nutritional state for $\mathrm{AD}$ prevention or treatment.

\section{METHODS}

\section{Search Strategies and Selection of Studies}

The review was conducted in accordance with the "Preferred Reporting Items for Systematic reviews and Meta-Analyses" (PRISMA) statement (Moher et al., 2010) and was registered in PROSPERO (CRD42021254557). We searched relevant literature from PubMed, Web of Science, China National Knowledge Infrastructure (CNKI), and WANGFANG, selecting studies from 1991 to 2021. The search terms were "magnesium," “Alzheimer's

\footnotetext{
Abbreviations: AD, Alzheimer's disease; AAS, atomic absorption spectrometry; $\mathrm{CI}$, confidence interval; CNKI, China National Knowledge Infrastructure; CSF, cerebrospinal fluid; HCs, healthy controls; ICP-AES, inductively coupled plasma-atomic emission spectrometry; ICP-MS, inductively coupled plasma-mass spectrometry; ISE, ion-selective electrode; SMD, standardized mean difference.
}

disease," "serum," "plasma," or "CSF." Both English and Chinese languages were used. The Supplementary Materials present the PRISMA checklist (Supplementary PRISMA Checklist) and detailed search strategy (Supplementary Methods: Search strategy). The inclusion criteria were: (1) case-control study design; (2) human subjects; (3) both $\mathrm{AD}$ and control groups described in terms of sample size and Mg concentration in serum, blood, plasma, or CSF. The exclusion criteria were: (1) letter, review, or case reports; (2) duplicated studies with repeated data; (3) in vitro or laboratory studies; (4) animal studies; (5) studies lacking quantitative data on $\mathrm{Mg}$ concentrations.

\section{Extraction of Data and Quality Evaluation}

The studies were evaluated separately by two authors (Ke Du and Xi Zheng) and the following details were extracted: first author, publication date (year), country, sample size, sex and age of participants, sample source, and measurement method. The mean values of $\mathrm{Mg}$ concentration and standard deviation (SD) were recorded; otherwise, they were estimated from sample characteristics (size, median, and range) (Hozo et al., 2005). If there was a disagreement when extracting the data, it need to be discussed by all authors, and the final reasonable data was determined by the corresponding author. The nine-star Newcastle-Ottawa Scale (NOS) was used for quality assessment.

\section{Statistical Analysis}

Statistical analyses were performed using STATA 12.0 (Stata, College Station, TX, USA). As the heterogeneity was significant, the results from the studies were combined using a randomeffects model. The standardized mean difference (SMD), which standardizes the outcome for multiple studies to the effect size found in terms of the SD, was used as the summary statistic.

The Chi-square and I-square tests were used to assess heterogeneity. A subgroup analysis was then used to assess possible sources of heterogeneity, estimating the influences of different methods of $\mathrm{Mg}$ determination and different geographical locations of the populations. Meta-regression was also used to evaluate the moderating effect of variables on the meta-analysis outcome, including two study level characteristics (age and sex distribution) while the impact of the individual studies on the pooled SMD was assessed using sensitivity analysis. Potential publication bias was evaluated with Egger's and Begg's tests, as well as the "trim and fill" method. Sensitivity analysis was conducted to explore whether a significant difference in one study could markedly influence the overall outcome; this was done by eliminating successive individual studies from the repeated analysis. Finally, temporal effects were determined by a cumulative meta-analysis.

\section{RESULTS}

\section{Selection of Studies}

Twenty nine possible studies were totally found after a preliminary search in PubMed, Web of Science, CNKI, and WANGFANG. Eight articles were excluded for overlap in studies $(n=3)$, no AD type dementia $(n=2)$, no healthy control $(n=$ 2 ), and unavailable serum, plasma, or CSF Mg levels $(n=1)$. As 


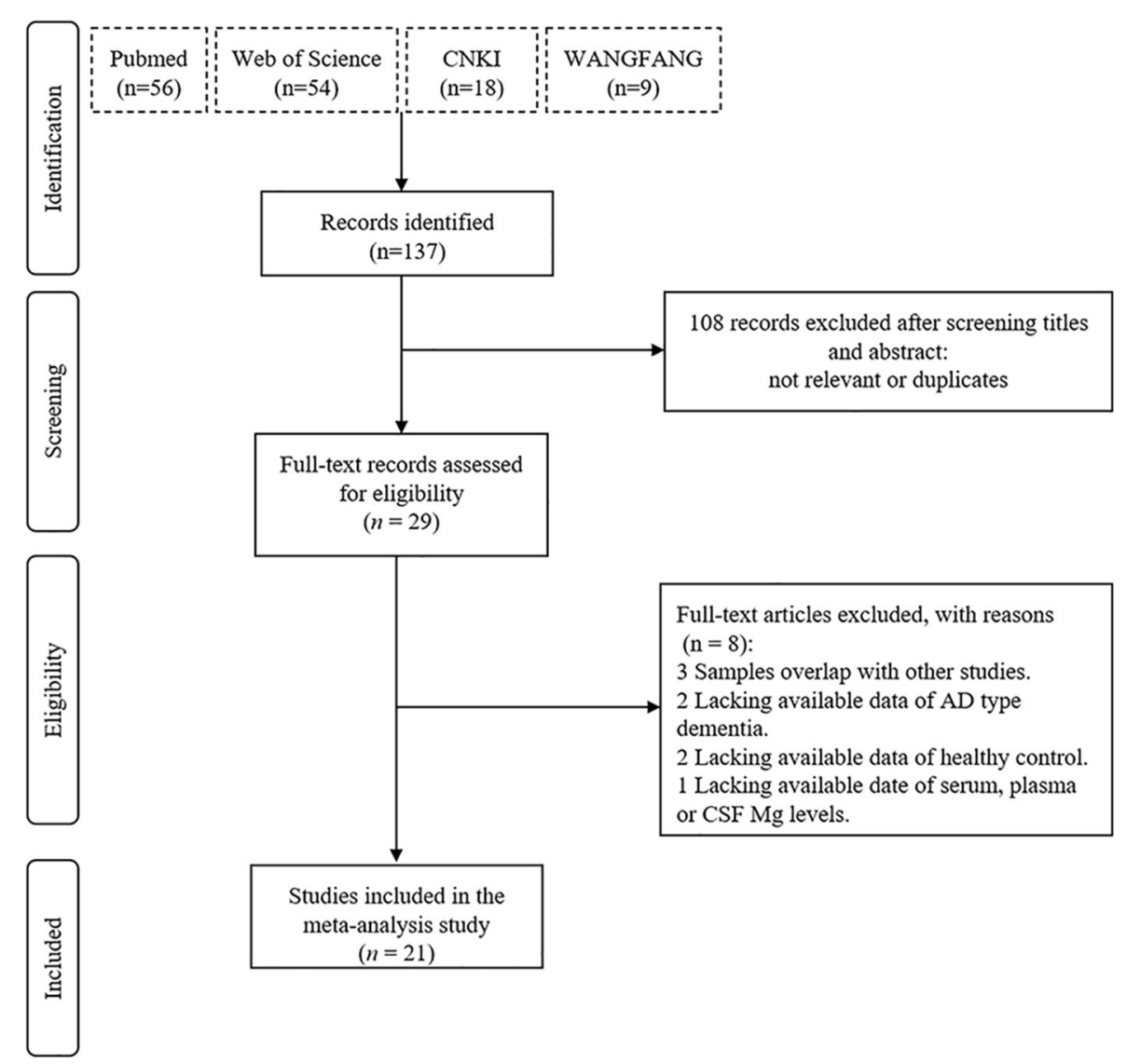

FIGURE 1 | Flowchart of the selection process.

a result, 21 articles were included in the current analysis $(1,112$ $\mathrm{AD}$ cases and 1,001 HCs). Figure 1 presents a flowchart of the study selection.

In the included studies, the sample sizes varied between 8 and 174. The subjects were between 44.8 and 78.8 years old, with the proportion of female subjects between 0 and $75 \%$. The geographical locations were Asia, Europe, and Africa. $\mathrm{Mg}$ concentrations were measured using atomic absorption spectrometry, inductively coupled plasma-atomic emission spectrometry, inductively coupled plasma-mass spectrometry, ion-selective electrode, and spectrophotometry. The average age was omitted in two studies. In addition, criteria for $\mathrm{AD}$ diagnosis were missing in two studies. The analytic method of $\mathrm{Mg}$ level in fluid were absent in one report. The details are listed in Table 1. The NOS quality assessment scale is shown in Supplementary Table 1. Most included studies were of high quality (18 high-quality and 3 moderatequality studies).

\section{Meta-Analysis of $\mathrm{Mg}$ Concentrations in Peripheral Blood}

Eighteen studies measured peripheral blood Mg levels in both AD patients and HCs. The pooled sample size contained 828 $\mathrm{AD}$ patients and $884 \mathrm{HCs}$ (Table 1). The results indicated that
$\mathrm{AD}$ patients had less $\mathrm{Mg}$ levels in peripheral blood than $\mathrm{HCs}$ $(\mathrm{SMD}=-0.89 ; 95 \% \mathrm{CI}[-1.36,-0.43] ; P=0.000$; Figure 2$)$. Heterogeneity among the included studies was observed $\left(I^{2}\right.$ $=94.4 \%, P=0.000)$. According to sample source, subgroups analysis demonstrated significant heterogeneity in each subgroup (Table 2) and Mg levels were less in AD patients compared with $\mathrm{HCs}$, in both serum subgroups (SMD $=-0.54 ; 95 \%$ CI $[-1.07$, $-0.01] ; P=0.045)$ and plasma subgroups (SMD $=-1.88$; 95\% CI $[-2.97,-0.79] ; P=0.001$ ) (Figure 3). Additionally, according to the method of $\mathrm{Mg}$ measurement or geographical location, high heterogeneity still was found in subgroup analyses (Table 2). These results suggested that the sample source, $\mathrm{Mg}$ measurement method, and geographical location did not contribute to heterogeneity. Meta-regression analyses showed that neither the mean age nor the sex of $\mathrm{AD}$ patients affected $\mathrm{Mg}$ levels in peripheral blood (mean age: $P=0.282$; sex: $P=0.103$ ), while sensitivity analyses revealed that the individual study had no influence on the overall results (Supplementary Table 2). The cumulative analysis excluded the temporal effects affecting the results of the pooled analysis. Besides, Egger's $(P=0.031)$ and Begg's $(P=0.028)$ tests suggested that publication bias might be possible. Accordingly, the "trim and fill" method was used for sensitivity analysis, and it was observed that the general result was not significantly altered $(\mathrm{SMD}=-1.05$; 95\% CI $[-1.55$, 
TABLE 1 | Characteristics of included studies in the meta-analysis.

\begin{tabular}{|c|c|c|c|c|c|c|c|c|c|c|c|c|}
\hline \multirow[b]{2}{*}{ References } & \multirow[b]{2}{*}{ Year } & \multirow[b]{2}{*}{ Country } & \multicolumn{4}{|c|}{ AD Patients } & \multirow[b]{2}{*}{ Criteria for AD Diagnosis } & \multicolumn{4}{|c|}{ Health Controls } & \multirow[b]{2}{*}{ Method } \\
\hline & & & $n$ & $\begin{array}{c}\text { Gender } \\
\text { (\% Female) }\end{array}$ & $\begin{array}{c}\text { Age } \\
(\text { Mean } \pm \text { SD) }\end{array}$ & $\begin{array}{l}\text { Mg concentration } \\
\text { mean } \pm \mathrm{SD}(\mathrm{mmol} / \mathrm{L})\end{array}$ & & $n$ & $\begin{array}{c}\text { Gender } \\
\text { (\% Female) }\end{array}$ & $\begin{array}{c}\text { Age } \\
(\text { Mean } \pm \text { SD) }\end{array}$ & $\begin{array}{l}\text { Mg concentration } \\
\text { mean } \pm \text { SD (mmol/L) }\end{array}$ & \\
\hline \multicolumn{13}{|l|}{ Studies on serum } \\
\hline Zhu et al. (1997) & 1997 & China & 8 & 0 & $75.0 \pm 8.0$ & $0.75 \pm 0.04$ & DSM-IIIR & 22 & 0 & $70.1 \pm 7.4$ & $0.83 \pm 0.03$ & AAS \\
\hline Cheng et al. (1999) & 1999 & China & 53 & 52 & $78.8 \pm 7.6$ & $0.87 \pm 0.07$ & DSM-IIIR & 49 & 61 & $77.1 \pm 4.3$ & $0.85 \pm 0.05$ & ICP-AES \\
\hline $\begin{array}{l}\text { Alimonti et al. } \\
\text { (2007) }\end{array}$ & 2007 & Italy & 53 & 68 & $74.5 \pm 6.5$ & $0.72 \pm 0.03$ & NINCDS-ADRDA & 124 & 35 & $44.8 \pm 12.7$ & $0.78 \pm 0.02$ & ICP-AES \\
\hline Cilliler et al. (2007) & 2007 & Turkey & 37 & 54 & - & $0.92 \pm 0.19$ & DSM-IV, NINCDS-ADRDA & 34 & - & - & $1.00 \pm 0.14$ & ICP-AES \\
\hline Liu (2008) & 2008 & China & 30 & 47 & $66.2 \pm 9.9$ & $0.041 \pm 0.01$ & DSM-IV, NINCDS-ADRDA & 28 & 46 & $66.8 \pm 8.3$ & $0.046 \pm 0.01$ & ICP-AES \\
\hline $\begin{array}{l}\text { Gustaw- } \\
\text { Rothenberg et al. } \\
\text { (2010) }\end{array}$ & 2010 & Poland & 30 & - & $69.1 \pm 5.3$ & $1.00 \pm 0.24$ & DSM-IV, NINCDS-ADRDA & 29 & - & $65.4 \pm 3.7$ & $0.782 \pm 0.10$ & Spectrophotometry \\
\hline $\begin{array}{l}\text { Barbagallo et al. } \\
\text { (2011) }\end{array}$ & 2011 & Italy & 36 & 58 & $73.1 \pm 0.9$ & $0.50 \pm 0.10$ & DSM-IV, NINCDS-ADRDA & 65 & 59 & $73.8 \pm 1.1$ & $0.53 \pm 0.10$ & ISE \\
\hline Singh et al. (2014) & 2014 & India & 100 & 47 & $62.7 \pm 7.2$ & $0.77 \pm 0.12$ & NINCDS-ADRDA & 100 & 39 & $59.7 \pm 8.1$ & $0.91 \pm 0.21$ & Spectrophotometry \\
\hline Wang (2015) & 2015 & China & 57 & 33 & $71.2 \pm 7.87$ & $1.40 \pm 0.36$ & DSM-IV, NINCDS-ADRDA & 96 & 49 & $68.2 \pm 7.7$ & $1.45 \pm 0.36$ & AAS \\
\hline Zheng (2015) & 2015 & China & 52 & 56 & $64.6 \pm 8.96$ & $1.00 \pm 0.10$ & NINCDS-ADRDA & 98 & 54 & $65.2 \pm 7.2$ & $0.98 \pm 0.16$ & - \\
\hline Koc et al. (2015) & 2015 & Turkey & 44 & 49 & $77.7 \pm 9.3$ & $0.72 \pm 0.17$ & DSM-IV, NINCDS-ADRDA & 33 & 52 & $73.2 \pm 10.6$ & $0.67 \pm 0.47$ & ICP-MS \\
\hline $\begin{array}{l}\text { Balmus et al. } \\
\text { (2017) }\end{array}$ & 2017 & Romania & 15 & 40 & $65.8 \pm 3.9$ & $0.39 \pm 0.11$ & NINCDS-ADRDA & 15 & 47 & $62.5 \pm 3.4$ & $0.54 \pm 0.09$ & AAS \\
\hline \multicolumn{13}{|l|}{ studies on plasma } \\
\hline Lemke (1995) & 1995 & Germany & 12 & 67 & $77.5 \pm 3.5$ & $0.58 \pm 0.07$ & DSM-IIIR & 12 & 50 & $75.2 \pm 6.4$ & $0.7 \pm 0.08$ & Spectrophotometry \\
\hline $\begin{array}{l}\text { Kurup and Kurup } \\
\text { (2003) }\end{array}$ & 2003 & India & 15 & 0 & 50-70 & $0.72 \pm 0.05$ & - & 15 & 0 & $50-70$ & $0.99 \pm 0.01$ & AAS \\
\hline $\begin{array}{l}\text { Bostrom et al. } \\
\text { (2009b) }\end{array}$ & 2009 & Sweden & 174 & 70 & $74 \pm 5.7$ & $0.89 \pm 0.09$ & NINCDS-ADRDA & 51 & 69 & $73 \pm 6.8$ & $0.88 \pm 0.10$ & ICP-MS \\
\hline Vural et al. (2010) & 2010 & Turkey & 50 & 54 & $71.9 \pm 6.8$ & $0.784 \pm 0.08$ & NINCDS-ADRDA & 50 & 52 & $65.1 \pm 7.1$ & $0.876 \pm 0.13$ & Spectrophotometry \\
\hline $\begin{array}{l}\text { Ahmed et al. } \\
\text { (2017) }\end{array}$ & 2017 & Saudi Arabia & 20 & 70 & $59.2 \pm 8.3$ & $0.38 \pm 0.19$ & - & 20 & 65 & $55.0 \pm 5.2$ & $1.02 \pm 0.13$ & spectrophotometry \\
\hline $\begin{array}{l}\text { Xu et al. (2018) } \\
\text { studies on CSF }\end{array}$ & 2018 & UK & 42 & 48 & $78.2 \pm 1.3$ & $0.70 \pm 0.06$ & NINCDS-ADRDA & 43 & 46 & $78.1 \pm 1.1$ & $0.70 \pm 0.07$ & ICP-MS \\
\hline $\begin{array}{l}\text { Bostrom et al. } \\
\text { (2009a) }\end{array}$ & 2009 & Sweden & 159 & 75 & $75.4 \pm 6.8$ & $1.15 \pm 0.08$ & NINCDS-ADRDA & 49 & 69 & $73.1 \pm 7.7$ & $1.18 \pm 0.09$ & ICP-MS \\
\hline $\begin{array}{l}\text { Hozumi et al. } \\
\text { (2011) }\end{array}$ & 2011 & Japan & 21 & 38 & - & $1.32 \pm 0.17$ & DSM-IV & 15 & 60 & - & $1.23 \pm 0.27$ & ICP-MS \\
\hline Jouini et al. (2021) & 2021 & Tunisia & 104 & 49 & $70.5 \pm 7.5$ & $1.13 \pm 0.11$ & DSM-IV, NINCDS-ADRDA & 53 & 53 & $68.5 \pm 7.5$ & $1.15 \pm 0.05$ & Spectrophotometry \\
\hline
\end{tabular}

NINCDS-ADRDA, National Institute of Neurological and Communicative Disorders and Stroke-Alzheimer's Disease and Related Disorders Association; DSM-IIIR or DSMIV, the Diagnostic and Statistical Manual for Mental Disorders; ICP-MS, inductively coupled plasma-mass spectrometry; ICP-AES, inductively coupled plasma-atomic emission spectrometry; AAS, atomic absorption spectrometry; ISE, ion-selective electrode. 


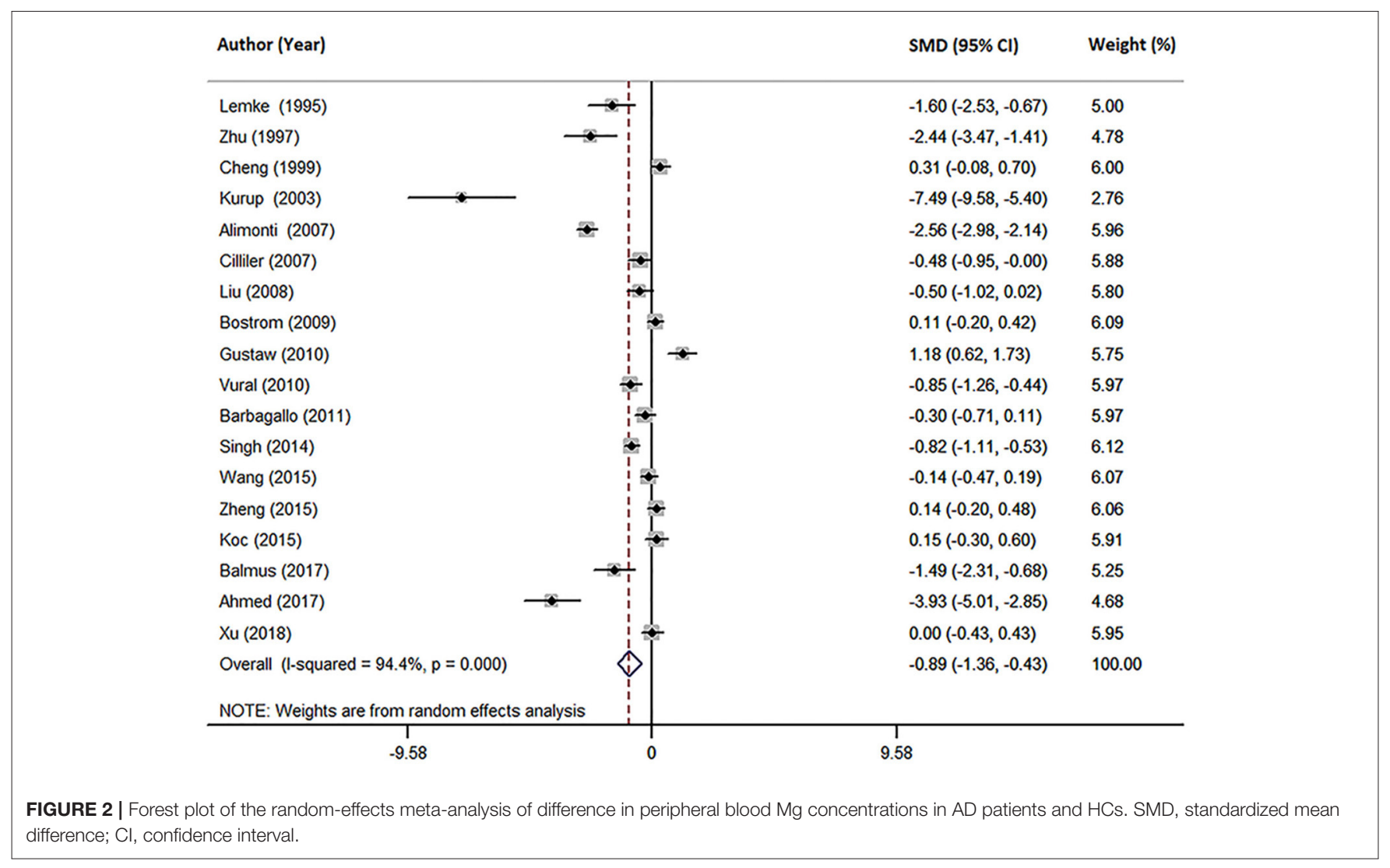

TABLE 2 | The subgroup analysis of studies reporting Mg levels in peripheral blood.

\begin{tabular}{lcccc}
\hline Subgroups & $\begin{array}{c}\boldsymbol{n} \text { of } \\
\text { studies }\end{array}$ & SMD $(\mathbf{9 5 \%}$ Cl) & $\mathbf{I}^{\mathbf{2}}$ & $\boldsymbol{P}$-value \\
\hline All studies & 18 & $-0.89(-1.36,-0.43)$ & $94.4 \%$ & 0.000 \\
Methods & & & & \\
AAS & 4 & $-2.62(-4.59,-0.66)$ & $95.5 \%$ & 0.000 \\
ICP-AES & 4 & $-0.81(-2.11,0.49)$ & $97.1 \%$ & 0.000 \\
Spectrophotometry & 5 & $-1.12(-2.19,-0.04)$ & $95.2 \%$ & 0.000 \\
ICP-MS & 3 & $0.09(-0.13,0.31)$ & $0.0 \%$ & 0.881 \\
ISE & 1 & $-0.30(-0.71,-0.11)$ & - & - \\
- & 1 & $0.14(-0.20,0.48)$ & - & - \\
Geographic locations & & & & \\
Asia & 11 & $-1.01(-1.54,-0.47)$ & $93.1 \%$ & 0.000 \\
Europe & 7 & $-0.65(-1.58,0.28)$ & $96.2 \%$ & 0.000 \\
\hline
\end{tabular}

ICP-MS, inductively coupled plasma-mass spectrometry; ICP-AES, inductively coupled plasma-atomic emission spectrometry; AAS, atomic absorption spectrometry; ISE, ionselective electrode.

-0.55 ]; $P=0.000$ ), indicating a lack of impact by unpublished negative data.

\section{Meta-Analysis of Mg Levels in CSF Between AD and HCs}

Three studies reported different CSF Mg levels in AD patients and HCs (Table 1). The pooled sample included 401 subjects, including $284 \mathrm{AD}$ patients and 117 HCs. Patients with $\mathrm{AD}$ showed a tendency toward lower CSF Mg levels compared with HCs, although this difference was non-significant (SMD $=-0.16 ; 95 \%$ CI $[-0.50,0.18] ; P=0.364 ;$ Figure 4). Due to the small number of studies, further analysis was not conducted.

\section{Meta-Analysis of Circulating Mg Levels in $A D$ and $H C s$}

Furthermore, we conducted a joint analysis of 21 studies investigating circulating $\mathrm{Mg}$ levels, including serum, plasma and CSF. The pooled sample size contained 2,113 subjects, including 1,112 $\mathrm{AD}$ patients and 1,001 HCs (Table 1). The results revealed that circulating $\mathrm{Mg}$ levels in $\mathrm{AD}$ patients were significantly decreased compared with that in HCs (SMD $=-0.74 ; 95 \%$ CI $[-1.13,-0.35] ; P=0.000$; Figure 5), in addition to high heterogeneity among these studies ( $I^{2}$ $=93.6 \%, P=0.006)$. Analysis of subgroups according to $\mathrm{Mg}$ measurement method and geographical location also showed significant heterogeneity (Table 3), suggesting that neither $\mathrm{Mg}$ measurement methods nor geographical location were the primary sources of heterogeneity. Neither the mean age nor sex of $\mathrm{AD}$ patients had obvious effects on circulating $\mathrm{Mg}$ levels by meta-regression analysis (mean age: $P=0.251$; sex: $P=0.111$ ), nor did individual studies influence the pooled SMD by sensitivity analysis (Supplementary Table 3). The cumulative meta-analysis did not show any significant 


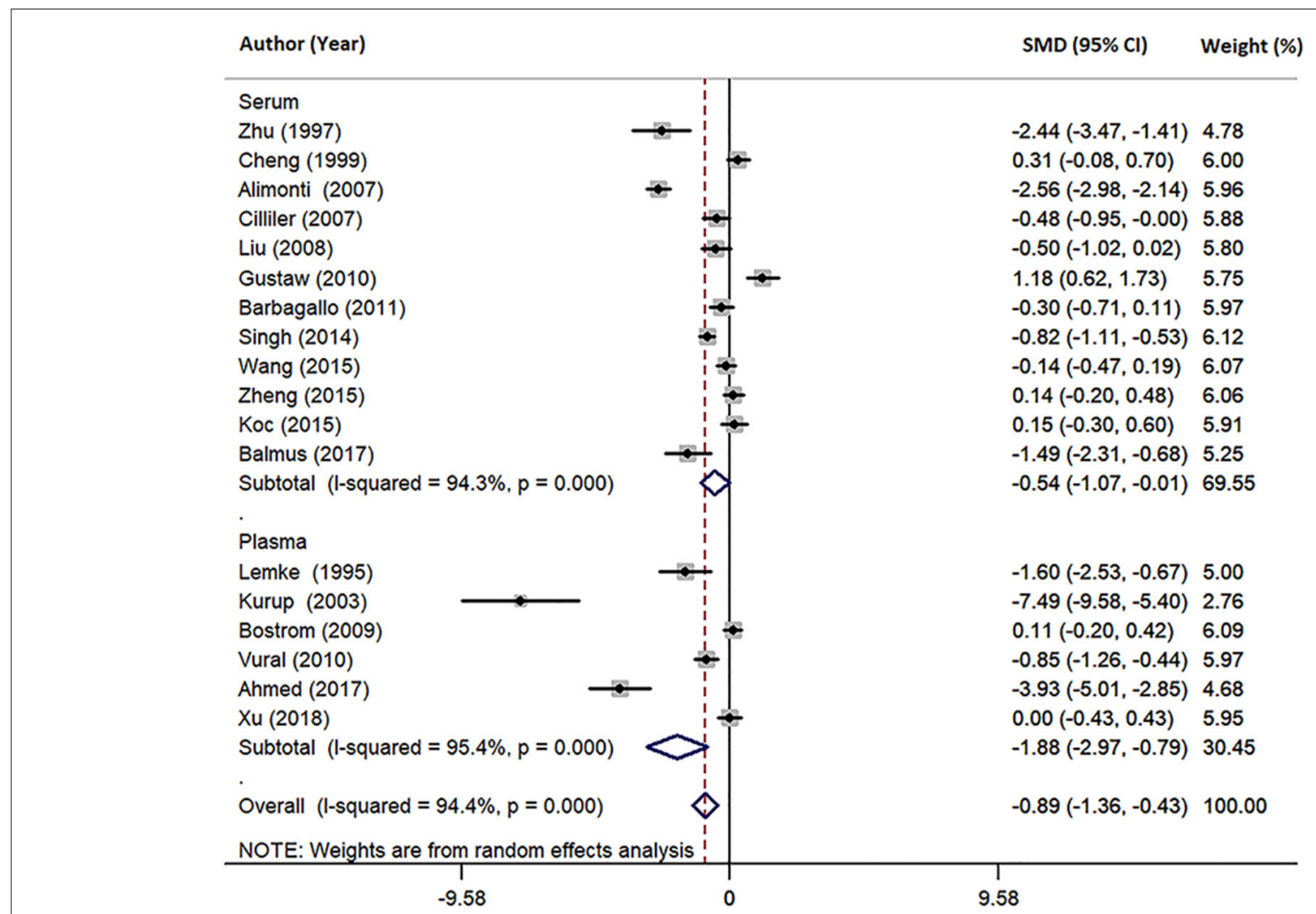

FIGURE 3 | Forest plot of subgroup analysis by sample source on differences in serum and plasma Mg between AD and HCs. SMD, standardized mean difference; $\mathrm{Cl}$, confidence interval.

\begin{tabular}{|c|c|c|}
\hline Author (Yest) & SMO (95\%(1) & weight $(x)$ \\
\hline Bectomentesos & 0.001000 .0099 & 4.110 \\
\hline 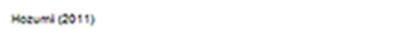 & $0.42(028.108)$ & 1857 \\
\hline $\operatorname{sonin}(2023)$ & $02110040,0.22)$ & $\infty z a$ \\
\hline 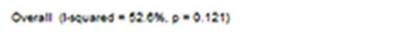 & $0.10(10.050 .0: 18)$ & 10000 \\
\hline 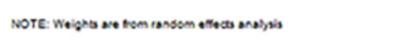 & & \\
\hline $\int_{-100}$ & 10 & \\
\hline
\end{tabular}

temporal biases. Egger's $(P=0.046)$ and Begg's $(P=0.037)$ tests indicated the potential publication bias. However, sensitivity analysis using the "trim and fill" method showed that the conclusion was not substantially altered (SMD $=-0.933 ; 95 \%$ CI $[-1.35,-0.52] ; P=0.000)$, indicating that the results were statistically robust. 


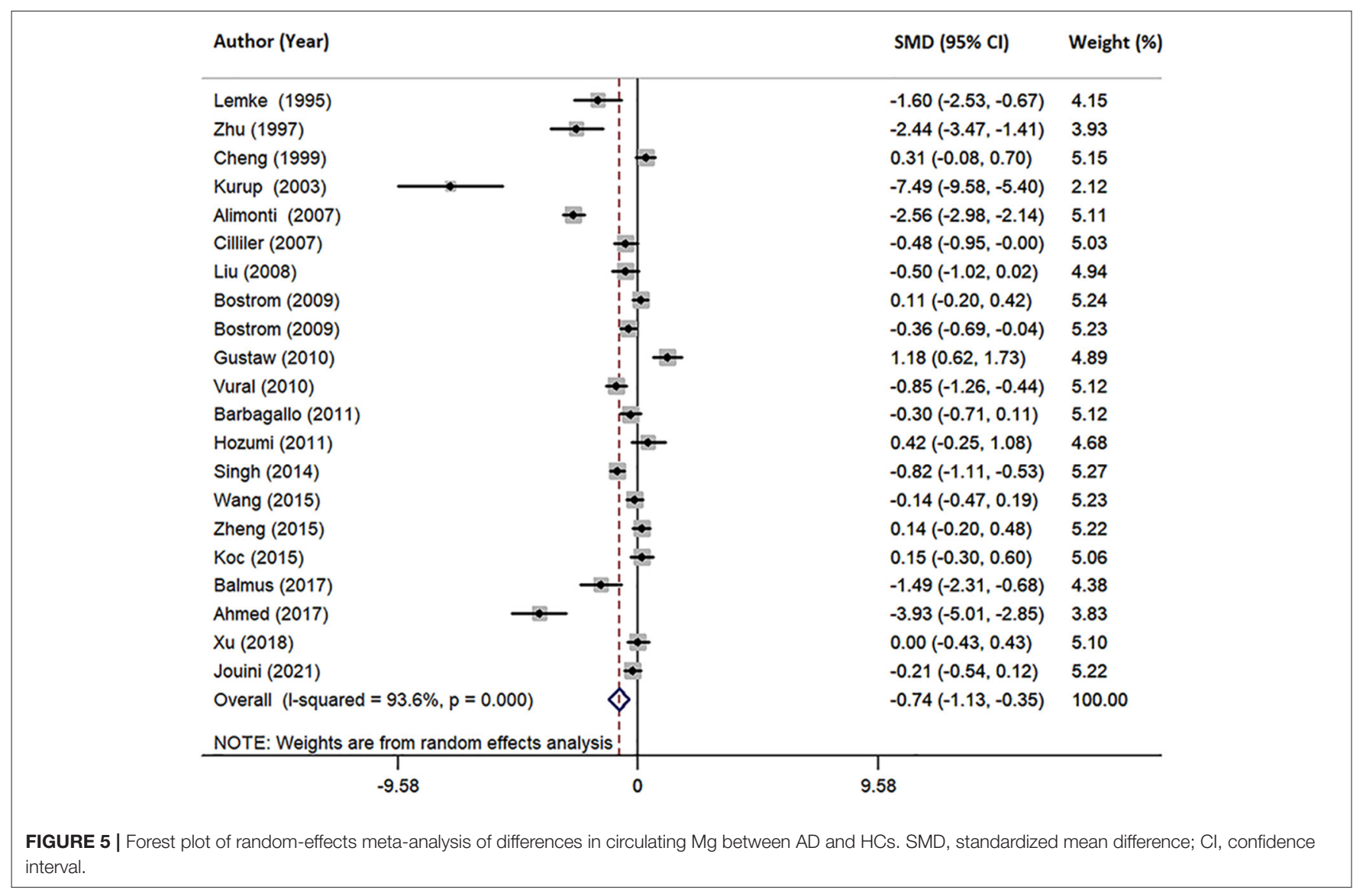

TABLE 3 | The subgroup analysis of studies reporting circulating Mg levels.

\begin{tabular}{lcccc}
\hline Subgroups & $\begin{array}{c}\boldsymbol{n} \text { of } \\
\text { studies }\end{array}$ & SMD (95\% Cl) & $\mathbf{I}^{\mathbf{2}}$ & $\boldsymbol{P}$-value \\
\hline All studies & 21 & $-0.74(-1.13,-0.35)$ & $93.6 \%$ & 0.000 \\
Methods & & & & \\
AAS & 4 & $-2.62(-4.59,-0.66)$ & $95.5 \%$ & 0.000 \\
ICP-AES & 4 & $-0.81(-2.11,0.49)$ & $97.1 \%$ & 0.000 \\
Spectrophotometry & 6 & $-0.93(-1.74,-0.11)$ & $94.4 \%$ & 0.000 \\
ICP-MS & 5 & $0.01(-0.24,0.25)$ & $44.4 \%$ & 0.126 \\
ISE & 1 & $-0.30(-0.71,-0.11)$ & - & - \\
- & 1 & $0.14(-0.20,0.48)$ & - & - \\
Geographic locations & & $-0.88(-1.39,-0.37)$ & $92.6 \%$ & 0.000 \\
Asia & 12 & $-0.61(-1.36,0.15)$ & $95.6 \%$ & 0.000 \\
Europe & 8 & $-0.21(-0.54,0.12)$ & - & - \\
Africa & 1 & & &
\end{tabular}

ICP-MS, inductively coupled plasma-mass spectrometry; ICP-AES, inductively coupled plasma-atomic emission spectrometry; AAS, atomic absorption spectrometry; ISE, ionselective electrode.

\section{DISCUSSION}

The challenges associated with various nutritional deficiencies and the role of nutritional supplementation have received more attentions owing to the high incidence of $\mathrm{AD}$ in aging population throughout the world (Chiu et al., 2014; Shlisky et al., 2017; Tan et al., 2019). Mg is an essential mineral involved in many AD-associated biological processes (Toffa et al., 2019). However, previous reports about the circulating $\mathrm{Mg}$ status in $\mathrm{AD}$ still remain controversial. The major findings of this study revealed that $\mathrm{Mg}$ concentrations in peripheral blood were significantly lower in $\mathrm{AD}$ patients. Furthermore, it was also consistent with the joint meta-analysis performed on serum, plasma, and CSF levels, increasing the statistical power of our meta-analysis. In addition, although AD patients showed a tendency toward decreasing $\mathrm{Mg}$ concentrations in the CSF compared with HCs, the difference was not statistically significant. Because the sample size were limited for the studies on CSF Mg levels (three studies, including $284 \mathrm{AD}$ patients and $117 \mathrm{HCs}$ ), further studies with large sample sizes are necessary to evaluate the CSF Mg levels in AD.

Consistent with our findings that $\mathrm{AD}$ patients present reduced circulating $\mathrm{Mg}$ levels, previous studies have suggested that $\mathrm{Mg}$ concentrations in the hair of $\mathrm{AD}$ patients were considerably less than controls (Kobayashi et al., 1989; Veronese et al., 2016). Additionally, $\mathrm{Mg}$ levels were lower in $\mathrm{AD}$ affected brain areas such as Ammon's horn, entorhinal cortex, and frontal cortex (Andrasi et al., 2000, 2005). However, the mechanisms underlying the reduced brain levels of $\mathrm{Mg}$ remain unclear. The barrier function of the blood-brain barrier (BBB) is possibly damaged during aging and AD (Yamazaki and Kanekiyo, 2017). Therefore, the reduced $\mathrm{Mg}$ levels in 


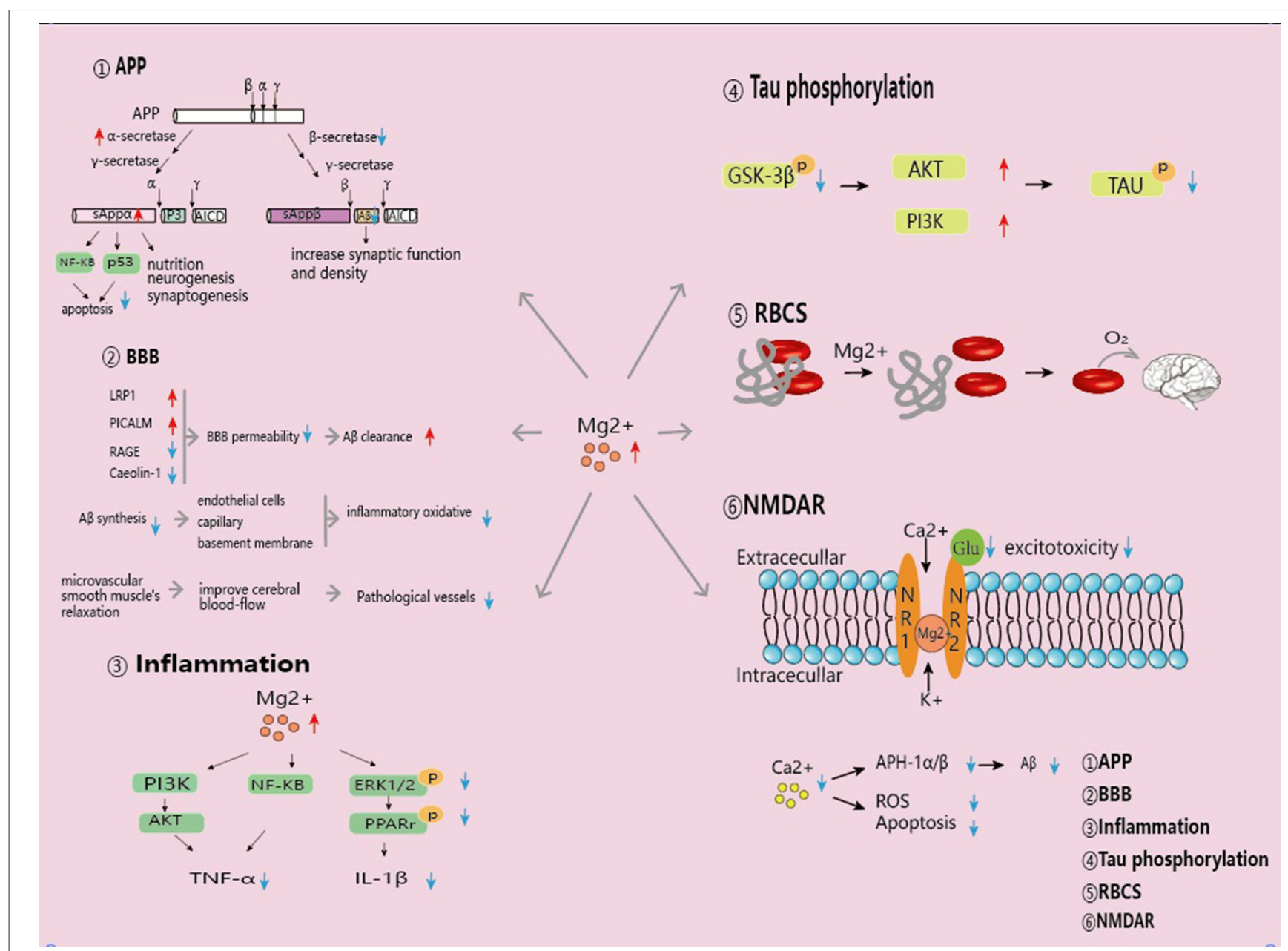

FIGURE 6 | Mg is involved in multiple steps of AD pathogenesis.

$\mathrm{AD}$-affected brains may be primarily attributed to disrupted BBB permeability. Nevertheless, the possibility of dietary deficiency cannot be ruled out, which requires further research to testify.

The normal range of circulating $\mathrm{Mg}$ levels may be also influenced by age, sex, sample type, and geographical location. Therefore, we have reviewed those factors in each study included in this meta-analysis, and found that in most studies these factors were matched between the $\mathrm{AD}$ and control groups. Therefore, these factors should not influence our results. As studies included in this meta-analysis focused on the AD patients, it is difficult to confirm the causal association between $\mathrm{Mg}$ deficiency and $\mathrm{AD}$. The dietary intake of $\mathrm{AD}$ patients is often poor in comparison with that of age-matched controls with normal cognitive function (Shatenstein et al., 2007). Therefore, $\mathrm{Mg}$ decrease may be a consequence of $\mathrm{AD}$, possibly induced by malnutrition and poor nutrient intake. In addition to $\mathrm{Mg}$, iron $(\mathrm{Fe})$ and copper $(\mathrm{Cu})$ are required for human health. Wang et al. did not observed the altered serum Fe levels in $\mathrm{AD}$ patients (Wang et al., 2015), whereas Ventriglia et al. described higher serum $\mathrm{Cu}$ concentrations in $\mathrm{AD}$ patients (Ventriglia et al., 2012). Therefore, these differences in circulating minerals could not be explained solely based on differences in dietary intake of $\mathrm{AD}$ patients. However, several studies have supported this causal relationship. For example, Cherbuin et al. reported that higher dietary $\mathrm{Mg}$ intake was associated with a lower risk of mild cognitive impairment (MCI) (Cherbuin et al., 2014). Glick and McMillan found that the cognitive decline associated with $\mathrm{AD}$ might be improved by increasing Mg dietary intake (Glick and McMillan, 2016). In addition, animal experiments have revealed the benefits of $\mathrm{Mg}$ supplementation on the performance of learning and memory. A study on rats pointed out that a formulated $\mathrm{Mg}$ compound administration increased the brain $\mathrm{Mg}$ levels and enhanced learning and working memory, as well as short-term synaptic facilitation and long-term potentiation (Slutsky et al., 2010). Increased Mg levels in the brain and plasma of elderly rats seemed to improve the maze performance and potentiation in the hippocampus after diet intake (Landfield and Morgan, 1984). Additionally, Yu et al. reported that high $\mathrm{Mg}$ concentration modulated $\mathrm{A} \beta$ protein precursor processing 
TABLE 4 | Mg intervention against pathological phenomena involved in AD.

\begin{tabular}{|c|c|c|c|c|c|}
\hline Reagent & In vivo model & In vitro model & Mechanism & Intervention effect & References \\
\hline $\begin{array}{l}\text { Magnesium-L- } \\
\text { threonate }\end{array}$ & Aged rats & - & $\begin{array}{l}\text { Enhance } \\
\text { NMDAR-dependent } \\
\text { signaling }\end{array}$ & $\begin{array}{l}\text { Enhance both short-term } \\
\text { synaptic facilitation and } \\
\text { long-term potentiation and } \\
\text { improve learning and } \\
\text { memory functions }\end{array}$ & Slutsky et al., 2010 \\
\hline Magnesium sulfate & - & $\begin{array}{l}\text { N2a cells stably } \\
\text { expressing PS1 and } \\
\text { APP }\end{array}$ & $\begin{array}{l}\text { Promote A } \beta \text { protein } \\
\text { precursor } \alpha \text {-cleavage } \\
\text { and modulate APP } \\
\text { retention on cell surface }\end{array}$ & $\begin{array}{l}\text { Reduce } A \beta \text { production and } \\
\text { demote the amyloidogenic } \\
\text { processing }\end{array}$ & Yu et al., 2010 \\
\hline $\begin{array}{l}\text { Magnesium sulfate } \\
\text { and magnesium } \\
\text { chloride }\end{array}$ & - & $\begin{array}{l}\text { BBB model constructed } \\
\text { from endothelial cells } \\
\text { and astrocytes }\end{array}$ & $\begin{array}{l}\text { Suppress Caveolin-1 and } \\
\text { RAGE while promote } \\
\text { PICALM and LRP1 } \\
\text { expression }\end{array}$ & $\begin{array}{l}\text { Reduce BBB permeability } \\
\text { and regulates } A \beta \\
\text { transcytosis }\end{array}$ & Zhu et al., 2018 \\
\hline Magnesium sulfate & $\begin{array}{l}\text { Streptozotocin- } \\
\text { induced sporadic } \\
\text { AD rats }\end{array}$ & - & $\begin{array}{l}\text { Inhibit GSK-3 } \beta \text {, increase } \\
\text { the activity of AKT and } \\
\text { PI3K }\end{array}$ & $\begin{array}{l}\text { Decrease tau } \\
\text { hyperphosphorylation, and } \\
\text { protect cognitive function } \\
\text { and synaptic plasticity }\end{array}$ & Xu et al., 2014 \\
\hline $\begin{array}{l}\text { Magnesium-L- } \\
\text { threonate }\end{array}$ & APP/PS1 mice & $\begin{array}{l}\text { A } \beta \text { or IL-1 } \beta \text {-induced } \\
\text { Glioblastoma A172 and } \\
\text { mouse brain D1A glial } \\
\text { cells }\end{array}$ & $\begin{array}{l}\text { Activate ERK } 1 / 2 \text { and } \\
\text { PPAR } \gamma \text { signaling } \\
\text { pathways }\end{array}$ & $\begin{array}{l}\text { Reduce IL-1 } \beta \text { expression } \\
\text { and neuroinflammation }\end{array}$ & Wang et al., 2017 \\
\hline $\begin{array}{l}\text { Magnesium-L- } \\
\text { threonate }\end{array}$ & APP/PS1 mice & $\begin{array}{l}\text { Human- or } \\
\text { mouse-derived glial and } \\
\text { neuronal cell lines }\end{array}$ & $\begin{array}{l}\text { Activate PI3K/AKT } \\
\text { signaling pathway and } \\
\text { inhibit NF-kB signaling } \\
\text { pathway }\end{array}$ & $\begin{array}{l}\text { Inhibit TNF- } \alpha \text { expression } \\
\text { and reduce the toxic } \\
\beta \text {-fragmentation of APP }\end{array}$ & Yu et al., 2018 \\
\hline Magnesium chloride & - & $\begin{array}{l}\text { Whole blood smears of } \\
\text { AD patients with or } \\
\text { without added Mg }\end{array}$ & $\begin{array}{l}\text { Disrupt RBC-parafibrin } \\
\text { aggregate }\end{array}$ & $\begin{array}{l}\text { Allow erythrocytes to return } \\
\text { to the circulation and } \\
\text { promote oxygen delivery to } \\
\text { the brain }\end{array}$ & $\begin{array}{l}\text { Lipinski and Pretorius, } \\
2013\end{array}$ \\
\hline $\begin{array}{l}\text { Magnesium-L- } \\
\text { threonate }\end{array}$ & APP/PS1 mice & - & $\begin{array}{l}\text { Protect NMDAR signaling } \\
\text { and reduce the } \\
\text { expression of BACE1 }\end{array}$ & $\begin{array}{l}\text { Prevent/reverse learning } \\
\text { and memory deterioration }\end{array}$ & Li et al., 2014 \\
\hline $\begin{array}{l}\text { Magnesium-L- } \\
\text { threonate }\end{array}$ & APP/PS1 mice & - & $\begin{array}{l}\text { Activate CaMKII and } \\
\text { CREB activation }\end{array}$ & $\begin{array}{l}\text { Improve recognition and } \\
\text { spatial memory }\end{array}$ & Huang et al., 2018 \\
\hline
\end{tabular}

NMDAR, N-methyl-D-aspartate receptor; PS1, presenilin 1; APP, amyloid- $\beta$ protein precursor; BBB, blood-brain barrier; RAGE, receptor for advanced glycation end products; PICALM, phosphatidylinositol binding clathrin assembly protein; LRP1, low-density lipoprotein receptor-related protein 1; GSK-3 $\beta$, glycogen synthase kinase-3 $\beta$; ERK, extracellular signal-regulated protein kinases; PPAR, peroxisome proliferator-activated receptor; NF-kB, nuclear factor-kB; TNF- $\alpha$, tumor necrosis factor- $\alpha$; RBC, red blood cells; BACE1, $\beta$-site amyloid precursor protein-cleaving enzyme 1; CaMKII, calcium-calmodulin dependent protein kinase Il; CREB, cAMP-response element binding protein.

and reduced $\mathrm{A} \beta$ secretion in a mouse neuroblastoma cells (Yu et al., 2010). $\mathrm{Mg}$ is postulated to target multiple steps and various stages of $\mathrm{AD}$ pathogenesis (Figure 6). It has been shown to promote $A \beta$ protein precursor $\alpha$-cleavage (Yu et al., 2010), increase $A \beta$ fibril clearance by regulating BBB permeability (Zhu et al., 2018), decrease tau hyperphosphorylation (Xu et al., 2014), inhibit A $\beta$-induced neuroinflammation (Wang et al., 2017; Yu et al., 2018), disrupt RBC (red blood cell)-fibrin aggregates which promotes oxygen delivery to the brain (Lipinski and Pretorius, 2013), and prevent the downregulation of N-methyl$\mathrm{D}$-aspartate receptors in $\mathrm{AD}$ models (Li et al., 2014; Huang et al., 2018) (Table 4). The present study increased statistical power by combining the results of different studies, and showed that $\mathrm{AD}$ patients have a poor circulating $\mathrm{Mg}$ status, further supporting the hypothesis that $\mathrm{Mg}$ deficiency is an $\mathrm{AD}$ risk factor. Based on these findings, clinical trials are demanded to explore the potential effects of $\mathrm{Mg}$ for $\mathrm{AD}$ prevention or treatment.
This meta-analysis has a few limitations. First, there are still few reports on CSF Mg levels although we have performed possibly comprehensive searches. Additional investigations with larger samples are required to confirm our findings. Second, circulating $\mathrm{Mg}$ levels varied among included studies. Typically, variations occur due to different techniques used for sampling or the analytic methods. Third, we just searched studies written in English or Chinese, studies in other languages were not included. Fourth, the high degree of heterogeneity among the studies necessitates cautious interpretation.

\section{CONCLUSIONS}

In summary, our analysis concluded that circulating $\mathrm{Mg}$ levels in $\mathrm{AD}$ patients were significantly lower than those in $\mathrm{HCs}$, providing more evidence that $\mathrm{Mg}$ supplementation or $\mathrm{Mg}$ rich diets possibly exerted a promising preventive or 
therapeutic strategies for treating $\mathrm{AD}$ patients with a poorer Mg status.

\section{DATA AVAILABILITY STATEMENT}

The original contributions presented in the study are included in the article/Supplementary Material, further inquiries can be directed to the corresponding author/s.

\section{AUTHOR CONTRIBUTIONS}

KD and M-YL contributed to the conception and design of the study. KD and XZ searched the databases, analyzed the data, and drafted the manuscript. KD, XZ, Z-TM, J-YL, and W-JJ screened the publications, conducted the quality assessment of the included studies, and extracted the data. M-YL had primary responsibility for the final content. All authors contributed to the writing, reviewing, and revising of the manuscript and read and approved the final manuscript.

\section{REFERENCES}

Abdullahi, I., Watila, M. M., Shahi, N., Nyandaiti, Y. W., and Bwala, S. A. (2019). Serum magnesium in adult patients with idiopathic and symptomatic epilepsy in Maiduguri, Northeast Nigeria. Niger J. Clin. Pract. 22, 186-193. doi: 10.4103/njcp.njcp_252_18

Ahmed, A. S., Elgharabawy, R. M., and Al-Najjar, A. H. (2017). Ameliorating effect of anti-Alzheimer's drugs on the bidirectional association between type 2 diabetes mellitus and Alzheimer's disease. Exp. Biol. Med. (Maywood) 242, 1335-1344. doi: 10.1177/1535370217711440

Akiyama, H., Barger, S., Barnum, S., Bradt, B., Bauer, J., and Cole, G. M. (2000). Inflammation and Alzheimer's disease. Neurobiol. Aging 21, 383-421. doi: 10.1016/S0197-4580(00)00124-X

Alimonti, A., Ristori, G., Giubilei, F., Stazi, M. A., Pino, A., Visconti, A., et al. (2007). Serum chemical elements and oxidative status in Alzheimer's disease, Parkinson disease and multiple sclerosis. Neurotoxicology 28, 450-456. doi: 10.1016/j.neuro.2006.12.001

Andrasi, E., Igaz, S., Molnar, Z., and Mako, S. (2000). Disturbances of magnesium concentrations in various brain areas in Alzheimer's disease. Magnes. Res. 13, 189-196.

Andrasi, E., Pali, N., Molnar, Z., and Kosel, S. (2005). Brain aluminum, magnesium and phosphorus contents of control and Alzheimer-diseased patients. J. Alzheimers Dis. 7, 273-284. doi: 10.3233/JAD-2005-7402

Balmus, I. M., Strungaru, S. A., Ciobica, A., Nicoara, M. N., Dobrin, R., Plavan, G., et al. (2017). Preliminary data on the interaction between some biometals and oxidative stress status in mild cognitive impairment and Alzheimer's disease patients. Oxid. Med. Cell Longev. 2017:7156928. doi: 10.1155/2017/7156928

Barbagallo, M., Belvedere, M., Di Bella, G., and Dominguez, L. J. (2011). Altered ionized magnesium levels in mild-to-moderate Alzheimer's disease. Magnes. Res. 24, S115-S121. doi: 10.1684/mrh.2011.0287

Belaidi, A. A., and Bush, A. I. (2016). Iron neurochemistry in Alzheimer's disease and Parkinson's disease: targets for therapeutics. J. Neurochem. 139, 179-197. doi: $10.1111 /$ jnc. 13425

Bostrom, F., Hansson, O., Blennow, K., Gerhardsson, L., Lundh, T., Minthon, L., et al. (2009a). Cerebrospinal fluid total tau is associated with shorter survival in dementia with Lewy bodies. Dement. Geriatr. Cogn. Disord. 28, 314-319. doi: $10.1159 / 000249145$

Bostrom, F., Hansson, O., Gerhardsson, L., Lundh, T., Minthon, L., Stomrud, E., et al. (2009b). CSF Mg and $\mathrm{Ca}$ as diagnostic markers for dementia with Lewy bodies. Neurobiol. Aging 30, 1265-1271. doi: 10.1016/j.neurobiolaging.2007.10.018

\section{FUNDING}

This study was supported by grants from National Natural Science Foundation of China (No. 81603112), Natural Science Foundation of Liaoning Province (2020-MS-161), Key Project of Basic Scientific Research project of Higher Education in Liaoning Province (LJKZ0775), and Liaoning Province Key Research and Development Plan guiding project (2018225089).

\section{ACKNOWLEDGMENTS}

We would like to thank Editage (www.editage.cn) for English language editing.

\section{SUPPLEMENTARY MATERIAL}

The Supplementary Material for this article can be found online at: https://www.frontiersin.org/articles/10.3389/fnagi. 2021.799824/full\#supplementary-material

Cheng, Y. M., Ge, W., Zhang, S. Y., Zhu, J. Z., He, T. M., and Ye, S. L. (1999) Study on calcium, magnesium, zinc and aluminum content in serum of senile dementia patients. Bull. Sci. Technol. 15, 467-469.

Cherbuin, N., Kumar, R., Sachdev, P. S., and Anstey, K. J. (2014). Dietary mineral intake and risk of mild cognitive impairment: the PATH through life project. Front. Aging Neurosci. 6:4. doi: 10.3389/fnagi.2014.00004

Chiu, H. Y., Yeh, T. H., Huang, Y. C., and Chen, P. Y. (2016). Effects of intravenous and oral magnesium on reducing migraine: a meta-analysis of randomized controlled trials. Pain Phys. 19, E97-E112. doi: 10.36076/ppj/2016.19.E97

Chiu, S., Woodbury-Farina, M. A., Shad, M. U., Husni, M., Copen, J., Bureau, Y., et al. (2014). The role of nutrient-based epigenetic changes in buffering against stress, aging, and Alzheimer's disease. Psychiatr. Clin. North Am. 37, 591-623. doi: 10.1016/j.psc.2014.09.001

Cilliler, A. E., Ozturk, S., and Ozbakir, S. (2007). Serum magnesium level and clinical deterioration in Alzheimer's disease. Gerontology 53, 419-422. doi: 10.1159/000110873

Dolati, S., Rikhtegar, R., Mehdizadeh, A., and Yousefi, M. (2020). The role of magnesium in pathophysiology and migraine treatment. Biol. Trace Elem. Res. 196, 375-383. doi: 10.1007/s12011-019-01931-Z

Donnelly, P. S., Xiao, Z., and Wedd, A. G. (2007). Copper and Alzheimer's disease. Curr. Opin. Chem. Biol. 11, 128-133. doi: 10.1016/j.cbpa.2007.01.678

Du, K., Liu, M., Pan, Y., Zhong, X., and Wei, M. (2017). Association of serum manganese levels with Alzheimer's disease and mild cognitive impairment: a systematic review and meta-analysis. Nutrients 9:231. doi: 10.3390/nu9030231

Glick, J. L., and McMillan, P. A. (2016). A multipronged, nutritional-based strategy for managing Alzheimer's disease. Med. Hypotheses. 91, 98-102. doi: 10.1016/j.mehy.2016.04.007

Gonzalez-Dominguez, R., Garcia-Barrera, T., and Gomez-Ariza, J. L. (2014). Characterization of metal profiles in serum during the progression of Alzheimer's disease. Metallomics 6, 292-300. doi: 10.1039/C3MT $00301 \mathrm{~A}$

Gustaw-Rothenberg, K., Kowalczuk, K., and Stryjecka-Zimmer, M. (2010). Lipids' peroxidation markers in Alzheimer's disease and vascular dementia. Geriatr. Gerontol. Int. 10, 161-166. doi: 10.1111/j.1447-0594.2009.00571.x

Hozo, S. P., Djulbegovic, B., and Hozo, I. (2005). Estimating the mean and variance from the median, range, and the size of a sample. BMC Med. Res. Methodol. 5:13. doi: 10.1186/1471-2288-5-13

Hozumi, I., Hasegawa, T., Honda, A., Ozawa, K., Hayashi, Y., Hashimoto, K., et al. (2011). Patterns of levels of biological metals in CSF differ among neurodegenerative diseases. J. Neurol. Sci. 303, 95-99. doi: 10.1016/j.jns.2011.01.003 
Huang, Y., Huang, X., Zhang, L., Han, F., Pang, K. L., Li, X., et al. (2018). Magnesium boosts the memory restorative effect of environmental enrichment in Alzheimer's disease mice. CNS Neurosci. Ther. 24, 70-79. doi: 10.1111/cns.12775

Jouini, N., Saied, Z., Ben Sassi, S., Nebli, F., Messaoud, T., Hentati, F., et al. (2021). Impacts of iron metabolism dysregulation on Alzheimer's disease. J. Alzheimers Dis. 80, 1439-1450. doi: 10.3233/JAD-201250

Kawahara, M., Tanaka, K. I., and Kato-Negishi, M. (2018). Zinc, carnosine, and neurodegenerative diseases. Nutrients 10:147. doi: 10.3390/nu10020147

Kirkland, A. E., Sarlo, G. L., and Holton, K. F. (2018). The role of magnesium in neurological disorders. Nutrients 10:730. doi: 10.3390/nu10060730

Kobayashi, S., Fujiwara, S., Arimoto, S., Koide, H., Fukuda, J., Shimode, K., et al. (1989). Hair aluminium in normal aged and senile dementia of Alzheimer type. Prog. Clin. Biol. Res. 317, 1095-1109.

Koc, E. R., Ilhan, A., Zubeyde, A., Acar, B., Gurler, M., Altuntas, A., et al. (2015). A comparison of hair and serum trace elements in patients with Alzheimer disease and healthy participants. Turk. J. Med. Sci. 45, 1034-1039. doi: 10.3906/sag-1407-67

Kurup, R. K., and Kurup, P. A. (2003). Hypothalamic digoxin, hemispheric chemical dominance, and Alzheimer's disease. Int. J. Neurosci. 113, 361-381. doi: $10.1080 / 00207450390162146$

Landfield, P. W., and Morgan, G. A. (1984). Chronically elevating plasma Mg2+ improves hippocampal frequency potentiation and reversal learning in aged and young rats. Brain Res. 322, 167-171. doi: 10.1016/0006-8993(84)91199-5

Lane, D. J. R., Ayton, S., and Bush, A. I. (2018). Iron and Alzheimer's disease: an update on emerging mechanisms. J. Alzheimers Dis. 64, S379-S395. doi: $10.3233 / \mathrm{JAD}-179944$

Lemke, M. R. (1995). Plasma magnesium decrease and altered calcium/magnesium ratio in severe dementia of the Alzheimer type. Biol. Psychiatry 37, 341-343. doi: 10.1016/0006-3223(94)00241-T

Lesne, S., Koh, M. T., Kotilinek, L., Kayed, R., Glabe, C. G., Yang, A., et al. (2006). A specific amyloid-beta protein assembly in the brain impairs memory. Nature 440, 352-357. doi: 10.1038/nature04533

Li, W., Yu, J., Liu, Y., Huang, X., Abumaria, N., Zhu, Y., et al. (2014). Elevation of brain magnesium prevents synaptic loss and reverses cognitive deficits in Alzheimer's disease mouse model. Mol. Brain 7:65. doi: 10.1186/s13041-014-0065-y

Lipinski, B., and Pretorius, E. (2013). The role of iron-induced fibrin in the pathogenesis of Alzheimer's disease and the protective role of magnesium. Front. Hum. Neurosci. 7:735. doi: 10.3389/fnhum.2013.00735

Liu, K. B. (2008). The Study of the Association Between Trace Element and Senile Dementia/Depressive Disorder. Jinan: Shandong University.

Mezzaroba, L., Alfieri, D. F., Colado Simao, A. N., and Vissoci Reiche, E. M. (2019). The role of zinc, copper, manganese and iron in neurodegenerative diseases. Neurotoxicology 74 230-241. doi: 10.1016/j.neuro.2019.07.007

Moher, D., Liberati, A., Tetzlaff, J., and Altman, D. G. (2010). Preferred reporting items for systematic reviews and meta-analyses: the PRISMA statement. Int. J. Surg. 8, 336-341. doi: 10.1016/j.ijsu.2010.02.007

Oyanagi, K., and Hashimoto, T. (2011). "Magnesium in Parkinson's disease: an update in clinical and basic aspects," in Magnesium in the Central Nervous System, eds R. Vink and M. Nechifor (Adelaide: Cambridge University Press). p. $229-236$.

Sensi, S. L., Granzotto, A., Siotto, M., and Squitti, R. (2018). Copper and zinc dysregulation in Alzheimer's Disease. Trends Pharmacol. Sci. 39, 1049-1063. doi: 10.1016/j.tips.2018.10.001

Sharma, K. (2019). Cholinesterase inhibitors as Alzheimer's therapeutics (Review). Mol. Med. Rep. 20, 1479-1487. doi: 10.3892/mmr.2019.10374

Shatenstein, B., Kergoat, M. J., and Reid, I. (2007). Poor nutrient intakes during 1-year follow-up with community-dwelling older adults with early-stage Alzheimer dementia compared to cognitively intact matched controls. J. Am. Diet Assoc. 107, 2091-2099. doi: 10.1016/j.jada.2007.09.008

Shen, Y., Dai, L., Tian, H., Xu, R., Li, F., Li, Z., et al. (2019). Treatment of magnesium-L-threonate elevates the magnesium level in the cerebrospinal fluid and attenuates motor deficits and dopamine neuron loss in a mouse model Of Parkinson's disease. Neuropsychiatr. Dis. Treat. 15, 3143-3153. doi: 10.2147/NDT.S230688

Shlisky, J., Bloom, D. E., Beaudreault, A. R., Tucker, K. L., Keller, H. H., Freund-Levi, Y., et al. (2017). Nutritional considerations for healthy aging and reduction in age-related chronic disease. Adv. Nutr. 8, 17-26. doi: 10.3945/an.116.013474

Singh, N. K., Banerjee, B. D., Bala, K., Basu, M., and Chhillar, N. (2014), Polymorphism in cytochrome P450 2D6, glutathione S-transferases Pi 1 genes, and organochlorine pesticides in alzheimer disease: a case-control study in North Indian population. J. Geriatr. Psychiatry Neurol. 27, 119-127. doi: $10.1177 / 0891988714522698$

Slutsky, I., Abumaria, N., Wu, L. J., Huang, C., Zhang, L., Li, B., et al. (2010). Enhancement of learning and memory by elevating brain magnesium. Neuron 65, 165-177. doi: 10.1016/j.neuron.2009.12.026

Tan, X., Zhang, Y., and Shao, H. (2019). Healthy China 2030, a breakthrough for improving health. Glob. Health Promot. 26, 96-99. doi: $10.1177 / 1757975917743533$

Toffa, D. H., Magnerou, M. A., Kassab, A., Hassane Djibo, F., and Sow, A. D. (2019). Can magnesium reduce central neurodegeneration in Alzheimer's disease? Basic evidences and research needs. Neurochem. Int. 126, 195-202. doi: 10.1016/j.neuint.2019.03.014

Ventriglia, M., Brewer, G. J., Simonelli, I., Mariani, S., Siotto, M., Bucossi, S., et al. (2015). Zinc in Alzheimer's disease: A meta-analysis of serum, plasma, and cerebrospinal fluid studies. J. Alzheimers Dis. 46, 75-87. doi: 10.3233/JAD-141296

Ventriglia, M., Bucossi, S., Panetta, V., and Squitti, R. (2012). Copper in Alzheimer's disease: a meta-analysis of serum, plasma, and cerebrospinal fluid studies. J. Alzheimers Dis. 30, 981-984. doi: 10.3233/JAD-2012-120244

Veronese, N., Zurlo, A., Solmi, M., Luchini, C., Trevisan, C., Bano, G., et al. (2016). Magnesium status in Alzheimer's disease: a systematic review. Am. J. Alzheimers Dis. Other Dement. 31, 208-213. doi: 10.1177/1533317515602674

Vural, H., Demirin, H., Kara, Y., Eren, I., and Delibas, N. (2010). Alterations of plasma magnesium, copper, zinc, iron and selenium concentrations and some related erythrocyte antioxidant enzyme activities in patients with Alzheimer's disease. J. Trace Elem. Med. Biol. 24, 169-173. doi: 10.1016/j.jtemb.2010.02.002

Wang, L. Z. (2015). A Case-Control Study for Relevant Factors of Alzheimer's Disease. Huhhot: Inner Mongolia Medical University.

Wang, P., Yu, X., Guan, P. P., Guo, J. W., Wang, Y., Zhang, Y., et al. (2017). Magnesium ion influx reduces neuroinflammation in Abeta precursor protein/Presenilin 1 transgenic mice by suppressing the expression of interleukin-1beta. Cell Mol. Immunol. 14, 451-464. doi: 10.1038/cmi.2015.93

Wang, Z. X., Tan, L., Wang, H. F., Ma, J., Liu, J., Tan, M. S., et al. (2015). Serum iron, zinc, and copper levels in patients with alzheimer's disease: a replication study and meta-analyses. J. Alzheimers Dis. 47, 565-581. doi: 10.3233/JAD-143108

Xu, J., Church, S. J., Patassini, S., Begley, P., Kellett, K. A. B., Vardy, E., et al. (2018). Plasma metals as potential biomarkers in dementia: a case-control study in patients with sporadic Alzheimer's disease. Biometals 31, 267-276. doi: 10.1007/s10534-018-0089-3

Xu, Z. P., Li, L., Bao, J., Wang, Z. H., Zeng, J., Liu, E. J., et al. (2014). Magnesium protects cognitive functions and synaptic plasticity in streptozotocin-induced sporadic Alzheimer's model. PLoS ONE 9:e108645. doi: 10.1371/journal.pone.0108645

Yamazaki, Y., and Kanekiyo, T. (2017). Blood-brain barrier dysfunction and the pathogenesis of Alzheimer's disease. Int. J. Mol. Sci. 18:1965. doi: $10.3390 /$ ijms 18091965

Yary, T., and Kauhanen, J. (2019). Dietary intake of magnesium and the risk of epilepsy in middle-aged and older Finnish men: a 22-year follow-up study in a general population. Nutrition 58, 36-39. doi: 10.1016/j.nut.2018.06. 019

Yu, J., Sun, M., Chen, Z., Lu, J., Liu, Y., Zhou, L., et al. (2010). Magnesium modulates amyloid-beta protein precursor trafficking and processing. $J$. Alzheimers Dis. 20, 1091-1106. doi: 10.3233/JAD-2010-091444

Yu, X., Guan, P. P., Zhu, D., Liang, Y. Y., Wang, T., Wang, Z. Y., et al. (2018). Magnesium ions inhibit the expression of tumor necrosis factor alpha and the activity of gamma-secretase in a beta-amyloid protein-dependent mechanism in APP/PS1 transgenic mice. Front. Mol. Neurosci. 11:172. doi: 10.3389/fnmol.2018.00172

Zheng, F. (2015). A case-control study on related influence factors of Alzheimer's disease. Changchun: Jilin University.

Zhu, D., Su, Y., Fu, B., and Xu, H. (2018). Magnesium reduces blood-brain barrier permeability and regulates amyloid-beta transcytosis. Mol. Neurobiol. 55, 7118-7131. doi: 10.1007/s12035-018-0896-0 
Zhu, M. W., Tang, H. C., and Zhao, L. (1997). Determination of trace elements in serum of senile dementia. Stud. Trace Elem. Health 14, 18-19.

Conflict of Interest: The authors declare that the research was conducted in the absence of any commercial or financial relationships that could be construed as a potential conflict of interest.

Publisher's Note: All claims expressed in this article are solely those of the authors and do not necessarily represent those of their affiliated organizations, or those of the publisher, the editors and the reviewers. Any product that may be evaluated in this article, or claim that may be made by its manufacturer, is not guaranteed or endorsed by the publisher.

Copyright $\odot 2022 \mathrm{Du}$, Zheng, Ma, Lv, Jiang and Liu. This is an open-access article distributed under the terms of the Creative Commons Attribution License (CC BY). The use, distribution or reproduction in other forums is permitted, provided the original author(s) and the copyright owner(s) are credited and that the original publication in this journal is cited, in accordance with accepted academic practice. No use, distribution or reproduction is permitted which does not comply with these terms. 